\title{
BAYH-DOLE REFORM AND THE PROGRESS OF BIOMEDICINE
}

\author{
ARTI K. RAI* AND REBECCA S. EISENBERG**
}

\section{INTRODUCTION}

Advances in fundamental biomedical research play an important and growing role in the development of new therapeutic and diagnostic products. Although the development of pharmaceutical end products has long been a proprietary enterprise, ${ }^{1}$ biomedical research comes from a very different tradition of open science. Within this tradition, longstanding norms call for relatively unfettered access to fundamental knowledge developed by prior researchers. ${ }^{2}$ The tradition of open science has eroded considerably over the past quarter century as proprietary claims have reached farther upstream from end products to cover fundamental discoveries that provide the knowledge base for future product development.

One important reason for this change has been a narrowing of the conceptual gap between fundamental research and commercial application. Once largely a matter of serendipity or trial-and-error, drug discovery is now critically dependent on basic knowledge of genes, proteins, and associated biochemical pathways. The foreseeable practical payoffs of this fundamental research make it easier to obtain patents for discoveries that, in an earlier era, would have seemed too far removed from useful applications for patent protection. As these early-stage advances in human understanding have become patentable,

Copyright (c) 2003 by Arti K. Rai and Rebecca S. Eisenberg

This article is also available at http://www.law.duke.edu/journals/66LCPRai.

* Assistant Professor, University of Pennsylvania Law School.

** Robert \& Barbara Luciano Professor, University of Michigan Law School.

The authors would like to thank Rochelle Dreyfuss, Kristin Madison, and John Walsh for helpful comments. Earlier versions of this paper were presented at Duke University's Conference on the Public Domain and at the University of Pennsylvania Law School. The authors thank the participants of these symposia for their helpful comments.

1. Various empirical studies have underscored the critical role played by patents on end-stage pharmaceutical products. See, e.g., Wesley Cohen et al., Protecting Their Intellectual Assets: Appropriability Conditions and Why U.S. Manufacturing Firms Patent (or Not), NATIONAL BurEAU OF ECONOMIC RESEARCH, Working Paper No. 7552 (2000) (discussing the importance of patents relative to other mechanisms of appropriation across various industries and concluding that patents are particularly important in the pharmaceutical arena); Richard C. Levin et al., Appropriating the Returns from Industrial Research and Development, in 3 BROOKINGS PAPERS ON ECONOMICS ACTIVITY 783 (Martin N. Baily et al, eds., 1987).

2. Indeed, at a certain point in time, these norms may have even called for resisting proprietary claims on relatively downstream research. As discussed further below, however, this time has long past. See infra Part III. 
new firms have emerged, raising capital to develop and market proprietary research that lies somewhere between traditional academic research and endproduct drug development.

This upstream shift in patenting activity has met little resistance from the courts. In 1980, the Supreme Court held that genetically engineered microorganisms were eligible for patent protection, construing the language of the patent statute as permitting patents for "anything under the sun that is made by man." Shortly thereafter, Congress created a specialized court to hear appeals in patent matters, the Court of Appeals for the Federal Circuit ("Federal Circuit"). ${ }^{4}$ The Federal Circuit has further extended the Supreme Court's expansive approach to patent eligibility ${ }^{5}$ while relaxing the stringency of standards for patent protection, such as utility ${ }^{6}$ and nonobviousness, ${ }^{7}$ that might otherwise have prevented the patenting of incremental advances in upstream biomedical research. The Federal Circuit's generally supportive attitude towards patents has encouraged imaginative claiming strategies and unprecedented levels of patenting activity.

These changes in the economic structure of research and in the case law have been important factors in promoting intellectual property claims in fundamental research discoveries. Perhaps an even more significant factor, however, has been the explicit U.S. policy of allowing grantees to seek patent rights in government-sponsored research results. This policy, which was codified beginning in 1980 with passage of the Bayh-Dole Act, ${ }^{8}$ and the StevensonWydler Act, ${ }^{9}$ has turned universities into major players in the biopharmaceutical patenting arena. The goal of these legislative initiatives was to promote widespread utilization of federally-sponsored inventions. The sponsors of the legislation believed that grantee ownership of patent rights, which would permit grantees to convey exclusive licenses to their inventions to private firms, was necessary to motivate private investors to pick up where government sponsors left off and transform new discoveries into commercial products. ${ }^{10}$ But the leg-

3. Diamond v. Chakrabarty, 447 U.S. 303, 309 (1980) quoting SEN. REP. NO. 1979 (1952).

4. See Federal Courts Improvement Act of 1982, Pub. L. No. 97-164, 96 Stat. 25 (codified as amended at 28 U.S.C. $\$ \S 41-49$ (1982)).

5. See, e.g., State St. Bank \& Trust Co. v. Signature Fin. Group, Inc., 149 F.3d 1368 (Fed. Cir. 1998) (holding that the concrete transformation of data made a mathematical algorithm patentable).

6. Compare Brenner v. Manson, 383 U.S. 519, $534-5$ (1966) (holding that a process patent may only be granted "where specific benefit exists in currently available form"), with In re Brana, 51 F.3d 1560, 1568 (Fed. Cir. 1995) (noting that "usefulness in patent law ... in the context of pharmaceutical inventions, necessarily includes the expectation of future R\&D”).

7. Compare Graham v. John Deere Co., 383 U.S. 1 (1966) (holding that an inquiry into the obviousness of an invention is a prerequisite to patentability), with In re Deuel, 51 F.3d 1552, 1559 (Fed. Cir. 1995) ("A general incentive [to try] does not make obvious a particular result.").

8. Act of Dec. 12, 1980, Pub. L. No. 96-517, § 6(a), 94 Stat. 3015, 3019-28 (1980) (codified as amended at 35 U.S.C. $\$ \S 200-212(1994))$.

9. Stevenson-Wydler Technology Innovation Act of 1980, Pub. L. No. 96-480, § 2, 94 Stat. 23112320 (1980) (codified as amended at 15 U.S.C. $\$ \S 3701-3714$ (2000)).

10. The Bayh-Dole Act states that its purpose is "to use the patent system to promote the utilization of inventions arising from federally funded research or development ...." 35 U.S.C. § 200 (emphasis added). 
islation draws no distinction between downstream inventions that lead directly to commercial products and fundamental research discoveries that broadly enable further scientific investigation. Universities have taken the opportunity to file patent applications on basic research discoveries, such as new DNA sequences, protein structures, and disease pathways, that are primarily valuable as inputs into further research, thereby accelerating the encroachment of the patent system into what was formerly the domain of open science. Even when they do not seek patents, universities often seek to preserve their expectations for profitable payoffs by imposing restrictions on the dissemination of research materials and reagents that might generate commercial value in subsequent research.

This frenzy of proprietary claiming has coincided with unprecedented levels of both public and private investment in biopharmaceutical research and development and impressive scientific and technological accomplishments. Paradoxically, however, in the long run, it may hinder rather than accelerate biomedical research. Although intellectual property rights may sometimes be necessary to motivate private firms to develop and disseminate university-based discoveries, the trend towards assertions of intellectual property rights by universities might also impede the progress of science. The challenge lies in distinguishing discoveries that are better developed and disseminated through open access from discoveries that are better developed and disseminated under the protection of intellectual property rights. Under the Bayh-Dole Act, institutions that perform funded research enjoy largely unfettered discretion to determine when intellectual property rights are appropriate. ${ }^{11}$ We argue, however, that it is the funding agencies that will often have a more appropriate combination of knowledge and incentives to make these determinations in furtherance of the overall public interest in research and product development. The Bayh-Dole Act should therefore be reformed to give funding agencies greater discretion to determine when to require that publicly-funded research discoveries be dedicated to the public domain. ${ }^{12}$

\section{II}

\section{THE INCREASINGLY PROPRIETARY CHARACTER OF UNIVERSITY-BASED BIOMEDICAL RESEARCH}

Even prior to passage of the Bayh-Dole Act of 1980, some agencies allowed universities to patent publicly-funded research discoveries. ${ }^{13}$ In the late 1970s, when research advances in molecular biology began to offer the promise of

11. See infra notes 70-72 and accompanying text.

12. By "public domain" we mean an arena where the research is either available free of charge or at a nominal fee that covers the marginal cost of production.

13. See Rebecca S. Eisenberg, Public Research and Private Development: Patents and Technology Transfer in Government-Sponsored Research, 82 VA. L. REV. 1663, 1683 (1996). Of particular relevance to biomedical research, the Department of Health, Education and Welfare (now Health and Human Services) allowed academic institutions with established technology licensing offices to patent the results of their research. Id. 
near-term commercial applications, grantees began to seek patents, ${ }^{14}$ and in 1979 universities received 264 patents. ${ }^{15}$ The patenting trend accelerated significantly, however, after the passage of the Bayh-Dole Act in $1980 .^{16}$ By 1997, the total number of patents issued annually to universities had increased to $2,436 .{ }^{17}$ This almost ten-fold increase in university patenting was significantly greater than the two-fold increase in overall patenting during the same time period, ${ }^{18}$ and substantially exceeded growth in university research spending. ${ }^{19}$

Biomedical research discoveries account for a major share of these university patents, particularly in terms of licensing revenues. ${ }^{20}$ Moreover, the majority of this research is publicly funded: Despite the increasingly intimate involvement of industry with universities, industry actually funds only a small percentage of university-based research in the life sciences. ${ }^{21}$ Many universityowned patents do not cover commercial end products, but rather fundamental research discoveries and research tools. For example, one recent study of Columbia University's patent portfolio indicates that more than $50 \%$ of its licensed patents represent research tools. ${ }^{22}$

A prominent recent example of a publicly-funded basic research discovery patented by a university is pluripotent primate embryonic stem cell lines. In the

14. See D.C. Mowery et al., The Growth of Patenting and Licensing by U.S. Universities: An Assessment of the Effects of the Bayh-Dole Act of 1980, 30 RES. POL'Y 99, 104 (2001).

15. Id.

16. See D.C. Mowery \& A.A. Ziedonis, Academic Patent Quality and Quantity Before and After the Bayh-Dole Act in the United States, 31 RESEARCH POLICY 399, 414-15 (2002) (noting that the apparent decline in "importance and quality of post-1980 U.S. academic patents may have resulted from the Bayh-Dole Act's encouragement of entry into patenting by academic institutions with relatively little experience in this activity").

17. Mowery, supra note 14 , at 104.

18. In 1979, a total of 48,854 utility patents were granted. By 1997, that number had increased to 111,983. See U.S. PATENT STATISTICS, CALENDAR YeARS, 1963-2000, available at http://www.uspto. gov/web/offices/ac/ido/oeip/taf/reports.htm\#PSR.

19. Mowery et al., supra note 14 , at 104 .

20. Id. at 117 (noting that leading patents at the University of California, Stanford, and Columbia "are concentrated in the biomedical arena"); see also Annetine C. Geljins \& Samuel O. Thier, Medical Innovation and Institutional Interdependence: Rethinking University-Industry Connections, 287 JAMA 72,75 (2002) (observing that medical center at Columbia accounts for nearly $85 \%$ of all licensed inventions).

21. David Blumenthal et al., Relationships Between Academic Institutions and Industry in the Life Sciences-An Industry Study, 334 NEw ENG. J. MED. 368, 369 (1996) (stating that industry funds 11.7\% of academic research in the life sciences and about $7 \%$ of university research in science as a whole). More generally, although overall spending on biomedical research by the private sector exceeds spending by the public sector, the public sector is still responsible for the majority of spending on basic research. According to one study, basic research represented only about $14 \%$ of all private sector pharmaceutical R\&D in the 1990s. TRENDS IN FEDERAL SUPPORT OF RESEARCH AND GRADUATE EDUCATION 80 (Stephen A. Merrill, ed. 2001).

22. Geljins \& Thier, supra note 20, at 74; see also, Jerry Thursby et al., Objectives, Characteristics, and Outcomes of University Licensing: A Survey of Major Universities (July 2000) (unpublished working paper, on file with authors) (concluding, based on a survey of 62 university technology transfer offices, that most licensed university technologies are "embryonic"). Some commentators define the term "research tool" more narrowly. See, e.g., Michelle R. Henry et al., DNA Patenting and Licensing SCIENCE, August 23, 2002 at 1279 (differentiating between research tools and research targets). We use the term "research tool" broadly to include materials, data and methods that are employed in the research that leads to an end product. 
1990s, the National Institute of Health ("NIH") sponsored research at the University of Wisconsin that succeeded in deriving embryonic stem cells from rhesus monkeys and macaques. The NIH-sponsored research on primates yielded a broad patent for the Wisconsin Alumni Research Foundation ("WARF"), the technology transfer arm of the University of Wisconsin. The patent covers all primate embryonic stem cell lines (which include, of course, human embryonic stem cell lines), and provides disclosure support for subsequently filed claims drawn more narrowly to human embryonic stem cell lines. ${ }^{23}$

Although NIH has a strong interest in ensuring widespread dissemination of broadly enabling research tools like stem cell lines for use across the broad spectrum of biomedical research, the Bayh-Dole Act seriously limits the extent to which NIH can oversee the use of intellectual property rights by its grantees. As long as the contractor is based in the United States, funding agencies such as $\mathrm{NIH}$ may restrict patenting only in "exceptional circumstances," when the agency determines that withholding title to the invention from the contractor will better promote the goals of the Act. ${ }^{24}$ The statute provides an elaborate administrative procedure for challenging such determinations, with a right of appeal to the United States Claims Court. ${ }^{25}$ The agency must also notify the Commerce Department, which has primary responsibility for administering the Bayh-Dole Act, each time it makes a determination of exceptional circumstances, and provide an analysis justifying the determination. ${ }^{26}$ If the Secretary of Commerce determines that "any individual determination or pattern of determinations is contrary to the policies and objectives of [the Bayh-Dole Act]," the Secretary must advise the head of the agency and the Administrator of the Office of Federal Procurement Policy and recommend corrective

23. James A. Thomson, Primate Embryonic Stem Cells, U.S. Patent No. 5,843,780 (issued December 1, 1998). At the time of his original patent application, University of Wisconsin Professor James Thomson had worked with stem cells in rhesus monkeys and macaques only. Nonetheless, the patent broadly claims all primate embryonic stem cells. Several years later, when Thomson isolated human embryonic stem cells, the University of Wisconsin filed a subsidiary, or divisional, application specifically claiming the human stem cells. This divisional application was issued on March 13, 2001. James A. Thomson, Primate Embryonic Stem Cells, U.S. Patent No. 6,200,806. Because of a moratorium on federal funding for research on human embryonic stem cells, Thomson's research on human stem cells was funded not by the federal government but by Geron, a private biotechnology firm. See National Research Council and Institute of Medicine, Stem Cell Research AND THE Future of Regenerative MEDicine 33 (2001). Geron agreed to provide funding in exchange for exclusive rights to six types of differentiated cells that could be derived from human stem cells. Wisconsin Alumni Research Foundation's Brief in Opposition to Geron Corporation's Fed. R. Civ. Pro. 12 (c) Motion for Judgment on the Pleadings, Wisconsin Alumni Research Foundation v. Geron, Case No. 01-C-0459-C at 2 (on file with author).

24. 35 U.S.C. $\$ 202$ (a)(i)-(ii) (2000).

25. 35 U.S.C. $\S 203(2)$; see also 35 U.S.C. $\S 202(b)(4)$ (providing for review of exceptional circumstances determinations under last paragraph of section 203(2)). The Commerce Department, to which Congress gave rulemaking authority under section 206 of the Bayh-Dole Act, has promulgated regulations which specify that administrative appeals must "afford the contractor the opportunity to appear with counsel, submit documentary evidence, present witnesses, and confront such persons as the agency may rely upon.” 37 C.F.R. § 401.4(b)(3) (2001).

26. 35 U.S.C. $\$ 202(b)(1)$. 
actions. $^{27}$ Perhaps not surprisingly, NIH declarations of exceptional circumstances have been extremely rare. ${ }^{28}$

In addition to these cumbersome provisions for withholding grantee patent rights ex ante in the terms of funding agreements, the Bayh-Dole Act also permits agencies to exercise statutory "march-in rights" ${ }^{29}$ ex post to compel licensing of university patents on inventions made in the course of previously funded research..$^{30}$ An agency can do so, however, only if it determines that the university (or its exclusive licensee) is not taking steps to achieve "practical application of the subject invention," " or if such licensing is necessary "to alleviate public health or safety needs or requirements for public use specified by Federal regulations. ${ }^{\prime 32}$ In contrast to the statute's more parsimonious approach toward ex ante restriction of patent rights in the terms of a grant, exercise of march-in rights is not subject to an overarching directive that it be "exceptional." ${ }^{33}$ Nonetheless, the Bayh-Dole Act seriously limits the value of march-in rights as a mechanism for achieving prompt dissemination by deferring such rights from taking effect pending elaborate administrative proceedings and

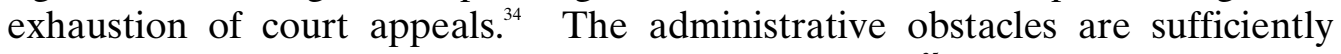
cumbersome that NIH has never exercised these rights. ${ }^{35}$

As universities have become more aggressive about claiming intellectual property rights, and as the conceptual gap between academic and industrial biomedical research has narrowed, commercial firms that might once have viewed academic researchers as benign, nonprofit benefactors of pre-market science have today come to view them instead as potential commercial rivals. An important consequence of this shift has been an increase in restrictions on the transfer of research tools, even those that are not patented. When universities supply research tools to private firms, they seek cash payments or reachthrough royalties on sales of future products in return. Although cash payments are less common when private firms supply academic researchers with research tools, firms typically require the scientist and the university to sign a material

27. Id.

28. The single case of which we are aware involved a declaration of exceptional circumstances issued in connection with a small project on cDNA sequencing funded by the National Cancer Institute. See NCI Solicitation, Molecular Target Laboratories, reprinted in COM. BUS. DAILY, February 24, 2000, available at 2000 WL 8961813.

29. 35 U.S.C. $\S 203(1)$.

30. Id.

31. 35 U.S.C. $\$ 203(1)(a)$, (b).

32. 35 U.S.C. $\S 203(1)(b)-(c)$.

33. 35 U.S.C. $\$ 203$.

34. 35 U.S.C. $\$ 203(2)$.

35. Indeed, a 1998 General Accounting Office report on administration of the Bayh-Dole Act determined that "[a]ccording to Commerce officials, no agency has yet taken back the title to any inventions because they were not being commercialized." U.S. GENERAL ACCOUNTING OFFICE, GAO/RCED-98-06, TECHNOLOGY TRANSFER: ADMINISTRATION OF THE BAYH-DOLE BY Research Universities 2 (1998). See, e.g., Barbara M. McGarey \& Annette C. Levey, Patents, Products and Public Health: An Analysis of the CellPro March-In Petition, 14 BERKELEY TECH. L. J. 1095 (1999). 
transfer agreement ("MTA") that may include grant-back provisions calling for an option to license patent rights to subsequent discoveries made through use of the tools. ${ }^{36}$ MTAs from both private firms and universities also typically prohibit researchers from sharing these tools with other institutions and call for pre-publication review of research results. ${ }^{37}$ Similar restrictions now appear in MTAs that govern purely academic exchanges of unpatented research tools between academic institutions. Institutional representatives balk at approving these agreements, which often leads to protracted negotiations, delays, and sometimes outright denial. ${ }^{38}$

\section{III}

\section{PROPRIETARY BARRIERS TO BIOMEDICAL RESEARCH \& DEVELOPMENT}

For a number of reasons, these proprietary claims threaten to impede biomedical research. First, and most obviously, patents on upstream discoveries hinder subsequent research by permitting owners to charge a premium for the use of discoveries that might otherwise be more cheaply available in a competitive market or in the public domain. Protection from price competition inevitably excludes some users who would be willing to pay marginal cost, but not the higher prices that patents permit. This inherent feature of patents is particularly troubling for biomedical research, given the importance to scientific progress of work by researchers in nonprofit institutions with limited resources for paying patent premiums.

The standard retort to this argument-that without patents to permit pricing in excess of marginal cost, no one would be motivated to incur R\&D expenses that were vulnerable to appropriation by free riders-is an empirical claim that is more plausible for discoveries that depend on private investment than for discoveries made with public funds. The more qualified argument for patents on government-sponsored research results - that without patents, these discoveries would languish in government and university archives, neglected by private firms as commercial non-starters-makes little sense for discoveries that can be

36. See Report of the NIH Working Group on Research Tools, at 4 (June 4, 1998), at http://www. nih.gov/news/researchtools/index.htm. One of the authors of this article (Eisenberg) chaired the Working Group that prepared this report.

37. Id. at 7-8.

38. Rebecca S. Eisenberg, Bargaining Over the Transfer of Proprietary Research Tools: Is This Market Failing or Emerging?, in EXPANDING THE BOUNDARIES OF INTELLECTUAL PROPERTY: INNOVATION POLICY FOR THE KNOWLEDGE SOCIETY 226 (Rochelle Dreyfuss et al. eds., 2001). A recent empirical study led by Eric Campbell indicates that $47 \%$ of geneticists who, in the preceding three years, had asked other faculty for additional data or materials regarding published research were denied such data or materials. See Eric G. Campbell et al., Data Withholding in Academic Genetics: Data From a National Survey, 287 JAMA 473, 478 (2002). This 47\% figure represented a substantial increase over the $34 \%$ figure reported in a prior study conducted in the mid 1990 s. The reasons cited by geneticists for denying data or materials included the need to honor the requirements of an industrial sponsor and the need to protect the commercial value of results. Id. at 478. The authors of the study also specifically note that academic scientists are most likely to encounter refusal when they seek access to biomaterials. The authors suggest that "it may be that material transfer agreements have become so complex and so demanding that they inhibit sharing." Id. at 479. 
broadly disseminated right away without further private investment. Free dissemination of discoveries that are still far removed from end product development will enable follow-on research that is likely to yield additional patents on discoveries made further downstream, closer to a marketable end product. As discussed further below, these downstream patents are generally far more important in motivating private firms to develop end products than upstream patents on prior discoveries owned by a university.

Some commentators have also argued that patents rarely impose high costs on academic research because patent holders practice an informal regime of price discrimination in favor of nonprofit researchers, primarily by not enforcing their patents against such researchers for non-commercial uses. ${ }^{39}$ But some patent holders have been more aggressive about insisting that university researchers sign license agreements,$^{40}$ especially when university researchers seek transfer of materials covered by a patent rather than simply practicing a patented invention inconspicuously in their own labs. Given that patent law offers no significant experimental use exemption from infringement liability, ${ }^{41}$ and that the division between non-commercial and commercial research can be blurry, it may be foolhardy for nonprofit researchers to rely on the forbearance of patent holders. ${ }^{42}$

Upstream patents may also hinder subsequent research if they give a single entity monopoly control of basic research discoveries that enable subsequent investigation across a broad scientific territory. Because the principle constraint on the scope of patent claims is prior knowledge in the field of the invention, this concern is particularly acute for patents on early-stage discoveries that open up new research fields (such as the discovery of pluripotent embryonic stem cells), as distinguished from narrower technological applications that grow out of and build incrementally upon existing knowledge in an established field. Unconstrained by prior art, such patents may be quite broad, permitting their owners to control subsequent research across a significant range of problems. The standard response to this argument is that profit-seeking owners of pioneer patents will find it in their own best interest to disseminate path-breaking dis-

39. See John Walsh, et al., The Patenting and Licensing of Research Tools and Biomedical Innovation, May 5, 2002 draft at 35 (on file with authors).

40. One notable example is DuPont, a firm that has generated considerable controversy in the scientific press over the restrictive terms of its research tool licenses to academic researchers. One controversial license involved DuPont's patented cre-lox gene knockout technology. The controversy over the cre-lox technology was resolved only after NIH threatened to boycott the technology unless DuPont allowed broader use by academic licensees. See Memorandum of Understanding (July 1, 1998), available at http://ott.od.nih.gov/textonly/cre-lox.htm. More recently, DuPont has engendered controversy in the context of sub-licenses to use oncomouse technology, which DuPont controls as exclusive licensee under a patent owned by Harvard University. Eliot Marshall, DuPont Ups Ante on Use of Harvard's OncoMouse, SCIENCE, June 21, 2002 at 2112.

41. See Madey v. Duke University, 307 F.3d 1351 (Fed. Cir. 2002).

42. Reliance on forbearance may be particularly foolhardy given the availability of treble damages for willful infringement. 
coveries to as many follow-on improvers as possible. ${ }^{43}$ Unfortunately, this prediction is belied by historical examples in many industries, including the electrical lighting, radio, automobile, and aircraft industries. In these industries, holders of broad patents were unable or unwilling to grant licenses to potential competitors upon mutually agreeable terms. ${ }^{44}$ The argument that broad upstream patents will promote coordinated licensing depends on unrealistic assumptions about the information, foresight, and goals of people who are bargaining with current or potential scientific and commercial rivals. Given imperfect information, disparate assessments of value, and the danger that pioneer patent holders will simply misappropriate the confidential research plans of follow-on researchers once they are disclosed in the course of negotiations, the transaction costs associated with such bargaining are likely to be quite high. ${ }^{45}$

Transaction costs mount quickly when the basic research discoveries necessary for subsequent work are owned not by one entity, but by a number of different entities. ${ }^{46}$ Concern about an anticommons, or "patent thicket," is quite pressing in contemporary biomedical research that draws upon many prior discoveries made by different scientists in universities and private firms. ${ }^{47}$ Exchanges of DNA sequences, laboratory animals, reagents, and data that were once subject to a normative expectation of free access are today subject to license agreements, material transfer agreements and database access agreements. These agreements need to be reviewed and renegotiated before research may proceed, imposing high transaction costs long before the research promises a likely revenue stream that would justify incurring these costs. A standard response to this concern-that market forces will motivate the emergence of patent pools and other institutions for bundling intellectual property rights, thereby reducing transaction costs and permitting the parties to realize

43. See generally Edmund Kitch, The Nature and Function of the Patent System, 20 J.L. \& ECON. 265 (1977).

44. See generally Robert Merges \& Richard Nelson, On the Complex Economics of Patent Scope, 90 COLUM. L. REV. 839, 885-91 (1990).

45. See Arti K. Rai, Fostering Cumulative Innovation in the Biopharmaceutical Industry: The Role of Patents and Antitrust, 16 BERKELEY TECH. L.J. 813, 833-34 (2001); Arti K. Rai, Regulating Scientific Research: Intellectual Property Rights and the Norms of Science, 94 Nw. U. L. REV. 77, 125-129 (1999) (discussing difficulties in achieving licensing of upstream patents).

46. It bears mention that the problems of unduly broad patent scope and proliferation of patent rights held by multiple owners can occur simultaneously. An initial broad patent on a pioneering research discovery doesn't necessarily preclude a proliferation of upstream patents related to that discovery. To the contrary, follow-on improvers often seek and obtain patent rights within the scope of the claims of the initial broad patent. In these "blocking patents" situations, parties need to crosslicense in order for further research to occur. For example, in the early years of the aircraft industry, the Wright Brothers held an initial broad patent on an aircraft stabilization system. Other companies were able, however, to secure blocking patents on improvements. Cross-licensing arrangements necessary for the production of aircraft could not be worked out until after the United States entered World War I. At that point, the Army and Navy intervened to impose cross-licensing. See JACOB A. VANDER MEulen, THE POLITICS OF AiRCRAFT 19-26 (1991).

47. Eisenberg, supra note 38; Michael A. Heller \& Rebecca S. Eisenberg, Can Patents Deter Innovation? The Anticommons in Biomedical Research, SCIENCE, May 1, 1998 at 698. 
gains from exchange ${ }^{48}$-is an empirical claim that has not yet been borne out by the experience of the biomedical research community. ${ }^{49}$ The public domain economizes on transaction costs by eliminating the need to find and bargain with patent owners, allowing research to proceed expeditiously and without the risk of bargaining breakdown.

Indeed, when stakeholders in the biopharmaceutical industry have seen the potential for an anticommons, they have reacted not by forming patent pools but, rather, by enhancing the public domain. The case of single nucleotide polymorphisms ("SNPs") provides an interesting example of this strategy. Collections of SNPs occurring throughout the genome are a useful resource for scientists searching for genes involved in specific diseases. ${ }^{51}$ SNPs also promise to be useful in developing diagnostic products to predict patient responses to drugs or other treatments. ${ }^{52}$ In recent years, various biotechnology companies have identified and sought patents on large numbers of SNPs, provoking concern on the part of both NIH and the pharmaceutical industry about the potential for balkanization of intellectual property rights in this important resource. Paradoxically, in the Bayh-Dole era, the pharmaceutical industry has enjoyed more latitude than NIH to respond effectively to this threat by placing SNPs in the public domain. Pharmaceutical companies have joined together with the nonprofit Wellcome Trust, a U.K.-based, non-governmental partner in the public Human Genome Project that is not bound by the Bayh-Dole Act, in a consortium to sponsor a SNP-identification effort with explicit instructions to put the information in the public domain. The SNP Consortium has candidly avowed a goal of defeating patent claims to SNPs. ${ }^{53}$ The willingness of private

48. E.g., Robert P. Merges, Contracting Into Liability Rules: Intellectual Property Rights and Collective Rights Organizations, 84 CALIF. L. REV. 1293 (1996).

49. In a recent paper based on interviews with researchers and executives from 25 biopharmaceutical firms, as well as researchers and technology transfer officers from 6 universities, John Walsh, Ashish Arora, and Wesley Cohen argue that examples of projects actually being stopped because of anticommons difficulties are rare. John Walsh, Ashish Arora, \& Wesley Cohen, The Patenting of Research Tools and Biomedical Innovation, draft at 15-16 (on file with author). They do note, however, that the presence of research tool patents can result in delay, costly negotiation, and even litigation. $I d$. at 31-35. The presence of these patents can also influence the choice of research project, $i d$. at $21-22$, particularly in cases where firms deny access to patents on biological targets. Id. at 28-31. Walsh and his co-authors also acknowledge that some anticommons problems have been alleviated not by traditional market responses but by shifts in the law that suggest a higher utility standard and narrower patent scope as well as by a variety of public and private efforts to enhance the public domain by thwarting the acquisition of upstream patent rights. See id. at 16, 46-48. Finally, the Walsh study indicates that some private firms are avoiding access difficulties by simply ignoring research tool patents and hoping that because of difficulties in detecting infringement, they won't be sued. Id. at 44-45. Although the study characterizes this firm behavior as a "working solution," one might question the long-term viability of a solution that is based on pervasive law-breaking that may yet trigger costly litigation when it comes to light.

50. SNPs are single base points within the genome at which the DNA sequence of individuals differs.

51. See, e.g., Leslie Roberts, SNP Mappers Confront Reality and Find it Daunting, SCIENCE, March 17,2000 at 1898 .

52. For a discussion of SNP-based "precision" therapies, see Allen D. Roses, Pharmacogenetics and the Practice of Medicine, 405 NATURE 857 (2000).

53. See SNP Consortium website, http://snp.cshl.org/about/ (last visited Nov. 19, 2002). 
firms in a patent-sensitive industry to spend money to enhance the public domain is powerful evidence of a perception that intellectual property rights in the research results could create significant barriers to subsequent research and product development. ${ }^{54}$

One set of responses to these problems might involve changing the patent laws to minimize the impact of patents on upstream research. One might, for example, reinvigorate the "products of nature" limitation on patent eligibility so as to exclude discoveries of DNA sequences, proteins, and biochemical mechanisms from patent protection, or to fortify the utility standard to limit the patenting of broadly enabling research tools. Another much-discussed idea is to provide an exemption from infringement liability for research, particularly noncommercial research..$^{55}$ Although such legal adjustments are worth considering, and some of them might be justified, ${ }^{56}$ it is difficult to calibrate these changes accurately, and the consequences of overdoing it could be grave. Patents clearly matter in the biopharmaceutical industry, and undue restrictions on patent protection may deter valuable private investment. While it is possible that biopharmaceutical firms, particularly those that produce end products, would benefit in the long term from restrictions on the upstream patents that feed into drug development, many of these firms continue to insist that they need patents on their research in order to attract risk capital for further development. ${ }^{57}$ Changes in the patent laws that exclude research tools from protection or exempt research activities from infringement liability could have a significant effect on the ability of these firms to raise funds for research. Given that overall private investment in biomedical $R \& D$ today exceeds public funding, the strong belief of private sector investors that patents are essential to their profit expectations urges caution in changing the underlying legal rules that support these investments.

54. The SNP consortium is not the only recent example of the private sector stepping forward to defend the public domain in the field of genomics. In the mid-1990s, the pharmaceutical company Merck sponsored an effort to put information about DNA fragments known as expressed sequence tags, or ESTs, into the public domain. More recently, Merck has sponsored a project to create 150 patent-free transgenic mice. Eliot Marshall, A Deluge of Patents Creates Legal Hassles for Research, SCIENCE, April 14, 2000, at 257. The private sector has also been collaborating with the NIH in sequencing the mouse genome and making this sequence publicly available. $I d$.

55. See, e.g., Janice M. Mueller, No "Dilettante Affair": Rethinking the Experimental Use Exception to Patent Infringement for Biomedical Research Tools, 76 WASH. L. REV. 1 (2001); Maureen O'Rourke, Toward a Doctrine of Fair Use in Patent Law, 100 CoLUM. L. REV. 1177 (2000); Genome Research and Diagnostic Accessibility Act of 2002, H.R. 3967, 107th Cong. 82.

56. We have begun to see some efforts in the direction of legal change. For example, the guidelines on utility issued by the PTO in 2001 exclude upstream research results from patent protection unless such research has a "specific, substantial, and credible" utility. See Utility Examination Guidelines, 66 Fed. Reg. 1092, 1098 (Jan. 5, 2001). In addition, various Federal Circuit decisions, and PTO guidelines implementing these decisions, indicate that the allowable scope of biotechnology claims may be relatively narrow. See Rai, supra note 45, at 840-41 (discussing decisions and PTO guidelines).

57. See, e.g., John Golden, Biotechnology, Technology Policy, and Patentability, 50 EMORY L.J. 101,167-72 (2001) (discussing widespread acceptance of the idea that small, capital-poor biotechnology companies need a patent portfolio to compete in the capital markets). 
When research is publicly sponsored, however, the argument for strong patent rights loses much of its force. The Bayh-Dole Act does not presume that patents are necessary to motivate grantees to perform research with federal funds, but rather that patents will promote subsequent utilization and development of inventions arising from federally supported research. The reasoning that lurks behind this presumption is that patents and exclusive licenses are essential to attract the private investment necessary to develop preliminary research discoveries into commercial products. In other words, without the security of a monopoly right to protect against rent-dissipating competition, the private sector would not be interested in product development. Whatever the merits of this presumption for patents on downstream inventions such as new drugs, it makes little sense for patents on broadly enabling upstream research technologies that are ready for dissemination to researchers in both the public and private sectors and may be put to use in the laboratory without further investment in developing them as products. Such technologies represent a significant share of the patent portfolios assembled by universities under the BayhDole Act.

A classic historical example of a federally-funded research technology for which exclusive rights were not necessary to achieve widespread dissemination and use is the Cohen-Boyer method for combining DNA from different organisms. ${ }^{58}$ Many observers attribute the rapid progress of the biotechnology industry to the fact that this technology was made widely available rather than licensed exclusively to a single firm. Although this pre-Bayh-Dole technology was in fact patented, the patents were licensed nonexclusively and cheaply to encourage firms to take licenses rather than to challenge the patents. These nonexclusive licenses generated considerable revenue for the universities that owned the patents, but it is difficult to see how they did anything to enhance profitability or otherwise motivate subsequent research and product development as contemplated by the Bayh-Dole Act. If anything, the patent royalties imposed a modest tax on product development. ${ }^{59}$ When a publicly-funded technology is licensed widely and nonexclusively the central, if not sole, function of the patent is to generate revenue for the patent owner. Although universities today may have great expectations of making money from their patent portfolios (even if these expectations have not, in most cases, thus far been fulfilled), ${ }^{60}$ this interest played little role in the original justification for the Bayh-Dole

58. For a description and analysis of the licensing of the Cohen-Boyer patents, see NATIONAL Research Council, InTEllectual PRoperty Rights and RESEARCH TOOLS IN MOLECUlaR BIOLOGY 40-42 (1997).

59. Id. at 41-42 (quoting Lita Nelsen, director of the Technology Licensing Office at the Massachusetts Institute of Technology).

60. A few schools have reaped much of the monetary gain. In 2000, the five top-grossing schools brought in $\$ 570$ million from technology licensing. This represents about half of the $\$ 1.26$ billion earned by all schools in that year. See 2000 Survey, Association of University Technology Managers (2000), available at http://www.autm.net/surveys/2000/summarynoe.pdf [hereinafter 2000 Survey] (last visited Jan. 22, 2003). 
Act. ${ }^{61}$ It is worth considering whether fundamental research tools that may be effectively disseminated and put to use through nonexclusive licensing should be patented at all, or whether the purposes of the Bayh-Dole Act would be better served by making them broadly available at minimal cost or in the public domain.

Of potentially greater concern, the Bayh-Dole Act does little to ensure that a university that patents such a broadly enabling technology will license the patent nonexclusively. To the contrary, Congress was careful in the terms of the Bayh-Dole Act and subsequent legislation to give universities discretion to grant exclusive licenses, consistent with its goal of using patents to motivate licensees to invest in further technology development by protecting them from competition. $^{6}$ But whether or not exclusive licensing is necessary to achieve this goal, it may be more financially attractive to universities than nonexclusive licensing. Exclusive licenses typically command higher royalties than nonexclusive licenses, and firms holding exclusive licenses are more willing to reimburse for patent costs and to provide additional grant funding to the inventor. Indeed, the available empirical data suggest that the majority of university licenses to small firms are exclusive. ${ }^{63}$

A prominent example of exclusive licensing on a broadly enabling research tool is the previously noted patent on primate embryonic stem cell lines held by the Wisconsin Alumni Research Foundation ("WARF"). ${ }^{64}$ Under an agreement that provided one million dollars of research support for subsequent work by the inventor, WARF granted a broad exclusive license for commercial use of six important cell types that could be derived from these cell lines to a single private firm, Geron. ${ }^{65}$ Exclusive licenses on research tools with potentially broad applications threaten to throttle scientific progress by limiting the number of players in a developing field.

It is also unclear whether such exclusive licenses are necessary to further the Bayh-Dole Act's goal of promoting commercial product development. The farther removed university-based research discoveries are from end-product development, the more likely it is that subsequent research will generate additional patents that will be more important to the profit expectations of private investors than patents on the prior research. Indeed, patents on the many discoveries that enable product development are more likely to add to a product's costs than to enhance its profitability. Given that the long course of biophar-

61. Eisenberg, supra note 13, at 1698-1701.

62. Eisenberg, supra note 13, at 1698-99.

63. 2000 Survey, supra note 60 (indicating that $54 \%$ of licenses to small firms are exclusive, and $90 \%$ of licenses to startup firms are exclusive).

64. See supra note 23. As noted earlier, a divisional of the parent application specifically claims human embryonic stem cells.

65. As a consequence of media scrutiny, as well as pressure from NIH, WARF subsequently reversed its decision, sued Geron, and concluded an agreement to reduce the number of cell types to which Geron has an exclusive license from six to three. See Andrew Pollack, University Resolves Dispute on Stem Cell Patent License, N.Y.TiMES, Jan. 10, 2002, at C11. 
maceutical product development typically generates a great many patented inventions on the road to market, Congress' fear that potential new products would never be developed if the early discoveries from which they sprang remained unpatented seems quaintly out of touch with contemporary R\&D and patenting practices.

A recent example of a situation where patenting, and subsequent exclusive licensing, of a broadly enabling research discovery was not necessary for downstream development involves federally-funded research identifying a basic biochemical pathway known the NF-kB cell-signaling pathway. This research, which was done in the 1980s by scientists at Harvard, Massachusetts Institute of Technology ("MIT"), and the Whitehead Institute for Biomedical Research, led to a broad patent application claiming all drugs that worked by inhibiting NF$\mathrm{kb}$ cell-signaling. Because the NF-kB pathway has been implicated in diseases ranging from cancer and osteoporosis to atherosclerosis and rheumatoid arthritis, the patent, which finally issued in $2002,{ }^{66}$ may cover drug treatments for all of these diseases. Indeed, the academic institutions, together with their exclusive licensee Ariad Pharmaceuticals, are now suing Eli Lilly \& Co., claiming that Lilly's osteoporosis drug Evista and its sepsis drug Xigris work in a manner that infringes the NF-kB patent. ${ }^{67}$ Ariad has also sent letters to some 50 other companies with products that work via the NF-kB pathway, asking them for royalties on present or future product sales. Obviously, the companies that are now being asked to pay royalties did not need an exclusive license from Harvard, MIT, and Whitehead to motivate them to pursue product development. The prospect of obtaining patents on their own end-product drugs was sufficient. In this case, as in many others, upstream patents issued to academic institutions serve as a tax on innovation, diluting rather than fortifying incentives for product development. ${ }^{68}$

For many discoveries emerging from government-sponsored research, the benefits of patenting are low relative to its costs. But some discoveries, including some important research tools and enabling technologies generated in the course of publicly-sponsored research, undoubtedly require substantial commercial investment for reliable mass-production and widespread distribution. For example, technologies and machines for DNA sequencing and analysis, initially developed in academic laboratories, have required substantial follow-on investment by private firms to turn them into reliable and commercially avail-

66. Nuclear Factors Associated With Transcriptional Regulation, Patent No. 6,410,516, issued June $25,2002$.

67. Sharon Begley \& Laura Johannes, Ariad Alleges Eli Lilly Drugs Infringe on Biomolecule Patent, WALl ST. J., June 28, 2002, at C1.

68. Even patents on relatively downstream university-based research may be unnecessary for purposes of promoting follow-on R\&D. For example, the University of Rochester's federally funded research on the cox-2 enzyme, which is responsible for the inflammation process, has yielded a patent that claims inhibitors of this enzyme. The university has filed patent infringement actions against pharmaceutical companies that make such lucrative cox-2 inhibitor products as Vioxx and Celebrex. These pharmaceutical companies clearly did not require an exclusive license from Rochester to motivate their investments in developing cox-2 inhibitors. 
able laboratory equipment. ${ }^{69}$ Patents and exclusive licenses may be crucial to motivate this sort of investment.

The policy challenge is to devise a system that distinguishes cases in which proprietary claims make sense from cases in which they do not. The complexity of biomedical research makes this a formidable task, and the public interest in getting these determinations right demands assigning this task to an appropriate decision-maker. Ideally, decisions about the dividing line between the public domain and private property should be made by institutions that are in a position to appreciate the tensions between widespread access and preservation of commercial incentives without being unduly swayed by institutional interests that diverge from the overall public interest. In the context of biomedical research, NIH may be the institution best suited for this task.

IV

\section{The Role of NIH IN Preserving The Public Domain}

Under the Bayh-Dole Act, determinations of what to patent are assigned in the first instance to the institution receiving federal research funds-typically a university in the case of NIH-sponsored biomedical research. ${ }^{70}$ Universities, in turn, have delegated this task to technology transfer professionals who are charged with building patent portfolios that will bring in revenue to the university. If the university declines to pursue patent rights on a particular invention, the sponsoring agency may claim ownership. ${ }^{71}$ If neither institution wants to patent the invention, the investigator may do so. ${ }^{72}$ In other words, if anyone involved in the research - the grantee, the sponsor, or the investigator-thinks the invention is worth patenting, that party may prevail over anyone who believes the invention should be left in the public domain. As noted earlier, the research sponsor may vary these rules in the terms of a funding agreement only in "exceptional circumstances," and only by complying with burdensome procedural safeguards.

In 1980, these restrictions on the ability of research sponsors to depart from the pro-patent presumption of the Bayh-Dole Act doubtless seemed sensible

69. In the case of the major DNA sequencing technology, an automated sequencer that relies on optical scanning and four-color fluorescent technology, the California Institute of Technology owns the first major patent. This patent was exclusively licensed to, and developed for commercial use by, a private firm, Applied Biosystems. See NATIONAL RESEARCH COUNCIL, supra note 58, at 46-48.

70. In keeping with its original title-the University and Small Business Patent Procedures Actthe Bayh-Dole Act also gives small businesses the right to seek patents on the results of their federally funded research. Congress was quite taken by the "very impressive record in technological innovation" complied by small businesses, S. REP. NO. 96-480, at 1 (1979), but initially rejected proposed legislation, Science and Technology Research and Development Utilization Policy Act, S. 1215 96th Cong. (1979), that would have extended the same rights to large businesses. Large business interests were not defeated for long, however. In 1983, President Reagan extended the right to retain patent ownership to large businesses in a Memorandum, and Congress quietly endorsed this extension the next year in an inconspicuous housekeeping provision to a 1984 change in the law. Trademark Clarification Act of 1984, 15 U.S.C. $\$ 1501$ (2000); 35 U.S.C. $\$ 210(c)$.

71. 35 U.S.C. $\$ 202(\mathrm{c})(2)$.

72. 35 U.S.C. $\$ 202(d)$. 
enough. At that time, university patenting was the exception rather than the rule, the biotechnology industry was in its infancy, and government research sponsors, particularly NIH, had a reputation for being hostile to patents to a degree that impeded development of new products and collaborations between academic and commercial investigators. ${ }^{73}$ The prevailing belief was that U.S. industry was missing opportunities to build upon a national advantage in university-based research because universities had no incentive to patent their discoveries and had to overcome strong bureaucratic resistance on the part of government sponsors to retain patent rights. ${ }^{74}$ The story Congress heard was that universities cared only about scientific recognition and were indifferent to patents, that private industry needed exclusive rights under university-owned patents to make product development profitable, and that government funding agencies had to be restrained from indulging their anti-patent reflexes so that universities and private industry could join forces to develop new technologies for the benefit of the U.S. economy.

Two decades later, much has changed. NIH and universities have become active patent claimants and collaborate with private industry across the spectrum of biomedical research. ${ }^{75}$ Universities are no longer indifferent to patents, but are eager to patent their discoveries in the hope of sharing in the bounty of future blockbuster products. ${ }^{76}$ Public research sponsors, such as NIH, have taken to heart their mandate to promote commercial product development as well as scientific progress. ${ }^{77}$ Product-developing firms lament patents on publicly sponsored discoveries as rent-diverting siphons as readily as they welcome them as rent-preserving protection from competition in potential product markets. Indeed, in the context of genome-related projects, the patent-sensitive pharmaceutical industry has repeatedly joined with NIH in calling for the dedication of new knowledge to the public domain. ${ }^{78}$

In this changed environment, the decision of Congress to divest funding agencies of any significant discretion to restrict patenting makes much less sense than it did in 1980. Indeed, because of the breadth of their missions and because of their dual roles as both patent owners who use their own patents to promote dissemination and development of new technologies and research sponsors who ultimately pay the costs that patents impose upon future research, public research sponsors are well-positioned to take into account the impact of

73. Eisenberg, supra note 13 , at 1692 . In addition to NIH, the Department of Defense was also perceived as resistant to giving patent rights to universities. Id. at 1692-93.

74. See id.

75. For a recent summary of products developed through NIH-funded research, see National Institutes of Health Response to the Conference Report Request for a Plan to Ensure Taxpayers' Interests are Protected (July 1, 2001), available at http://www.nih.gov/news/070101wyden.htm.

76. See supra notes 66-68 and accompanying text.

77. For example, in fiscal years 1993 to 1999, NIH executed 1,171 licenses based on NIH and FDA intramural invention portfolios. NIH royalties accounted for $70 \%$ of all federal royalties.

78. See supra notes 50-54 and accompanying text. 
upstream patents on both future product development and future scientific research.

Research sponsors like NIH have significant advantages in making these judgments over two other institutions that might choose what should be patented-Congress or the universities themselves. If Congress attempted to specify in any detail what criteria should determine decisions about patenting publicly-sponsored research, it would doubtless be faced with rent-seeking demands from every stakeholder potentially affected by its determination. Given that Congress has generally tended to accede to such demands, at least in the context of detailed intellectual property legislation, ${ }^{79}$ there is little reason to believe that criteria enunciated by Congress would promote the overall public interest. Moreover, Congress would be at a significant disadvantage in trying to formulate broadly applicable criteria ex ante, rather than making sensible choices about specific issues as they arise. By contrast, funding agencies are in a position to make case-by-case determinations and can readily modify their criteria in the face of new experiences.

As for the universities themselves, their self-interest is an imperfect proxy for the overall public interest, particularly given the large role played in university decision-making by technology transfer professionals who are not themselves academics. From a broad institutional perspective, universities both reap the rewards of the proprietary restrictions they impose on others and also pay the costs of restrictions that others impose on them. Thus, one might imagine that universities would have some interest in maintaining the public domain. The costs and benefits do not accrue, however, to the same university constituencies. The costs are largely borne by scientists who cannot get prompt access to the proprietary technologies they seek, while the gains from licensing revenues are much more salient to the technology transfer offices.

Even when universities recognize that the larger academic community might be better off sharing their research tools more freely, they face a serious collective action problem. So long as other institutions are staking out proprietary claims, no university is likely to forbear from asserting its own claims unilaterally. Traditional norms of open science may no longer be sufficient to address this collective action problem, ${ }^{80}$ especially given that the scientists who hold the norms do not necessarily make the ultimate decisions about asserting proprietary rights.

The limited success of the 1995 Uniform Biological Materials Transfer Agreement ("UBMTA") ${ }^{81}$ demonstrates the collective action problem. The UBMTA is a form contract designed to provide for relatively free exchange of

79. See generally Robert Patrick Merges \& Glenn Harlan Reynolds, The Proper Scope of the Copyright and Patent Power, 37 HARV. J. ON LEGIS. 45 (2000).

80. Cf. Elinor Ostrom, Governing THE COMmOns (1990) (discussing the use of norms to address the specific collective action difficulty associated with conservation of common-pool resources); see also ERIC POSNER, LAW AND SOCIAL NORMS 22-23 (2000) (discussing norms as an alternative to law in solving problems of collective action).

81. Uniform Biological Materials Transfer Agreement, 60 Fed. Reg. 12771 (March 8, 1995). 
unpatented research materials for research and educational purposes, in effect creating a limited public domain among universities. More than 100 universities, including all of the major research universities, have signed on to the UBMTA, and in so doing indicated their willingness to accept the agreement without further modification as the governing document for materials that their scientists receive from other institutions. ${ }^{82}$ Many of these same institutions, however, have substituted their own form agreement for the UBMTA when they send materials out to other universities. These different agreements may be more restrictive than the UBMTA in their terms and need to be reviewed by institutional representatives before they are signed. Such departures from the relatively nonrestrictive form agreement are unsurprising. The university technology transfer officials who draft agreements for the transfer of research materials tend to see their primary job as bringing licensing revenue into the university. ${ }^{83}$ Their ability to bring in license revenue may also be an important criterion by which their performance is assessed. Adherence to norms of open science is at odds with this primary mission and tempts technology transfer professionals to depart from the form whenever they think a particular material may have commercial value. The limited province of the UBMTA, which is not mandatory even for all exchanges among universities and makes no attempt to extend the principle of open access to exchanges between academic institutions and industry, opens the door for case-by-case departures that further weaken the power of the norms.

Left to their own devices, universities may be unable to take sustained collective action in favor of the public domain. For this reason, the role of NIH is crucial. On a number of occasions, NIH has been able to use hortatory strategies to convince academic institutions to act collectively to keep basic research information in the public domain. For example, leaders of the National Human Genome Research Institute ("NHGRI"), together with the Wellcome Trust and academic researchers at the major human genome mapping centers, resolved in February 1996 that "all human genomic DNA sequence information generated by centers funded for large-scale human sequencing should be freely available and in the public domain in order to encourage research and development." NHGRI followed up with an April 1996 policy statement making "rapid release of data into public databases" a condition for grants for large-scale human

82. See id.

83. See Thursby et al., supra note 22 (finding, based on survey of 62 universities, that securing royalty and licensing fees was most important objective of technology transfer officers). Indeed, at a recent meeting of the Advisory Committee to the NIH Director, William Brody, the President of Johns Hopkins University, noted that even higher level university administrators are being pressured by their boards and by local or state government officials to develop technology transfer offices into profit centers. See Minutes of the Meeting of the Advisory Committee to the Director (December 7, 2000) available at $\mathrm{http}: / / \mathrm{www}$. nih.gov/about/directors/120700min.htm.

84. Eliot Marshall, Genome Researchers Take the Pledge: Data Sharing, SCI., April 26, 1996 at 477. This pledge, known as the "Bermuda resolution," echoed conclusions reached in earlier reports from the NIH Ad Hoc Program Advisory Committee on Complex Genomes and the National Research Council (a division of the National Academies). 
genome sequencing. ${ }^{85}$ NIH could not, however, go so far as to forbid its grantees from filing patent applications without relying on the cumbersome "exceptional circumstances" clause of the Bayh-Dole Act. ${ }^{86}$ Rather than take this step, NIH declared that raw human genomic DNA sequence information should not be considered patentable as a matter of doctrine and policy. ${ }^{87}$ The statement also warned that NHGRI would monitor whether grantees were patenting "large blocks of primary human genomic DNA sequence" and might invoke the "exceptional circumstances" limitation in future grants. ${ }^{88}$ In the specific context of large-scale genome mapping, universities were willing to embrace a limited patenting norm, ${ }^{89}$ and there was no need to invoke the "exceptional circumstances" clause.

NIH undertook a similar strategy for SNPs. Before the SNP Consortium stepped forward to put SNPs in the public domain, NIH had decided to allocate public funds for SNP identification..$^{90}$ Once again, NIH refrained from invoking the "exceptional circumstances" provision of the Bayh-Dole Act." Instead, in its request for applications for SNP-related grants, NIH stressed the importance of making information about SNPs readily available to the research community and asked grant applicants to specify their plans for sharing data, materials and software. ${ }^{22} \mathrm{NIH}$ also specified that NIH staff would consider the adequacy of the plan for sharing and data release as one of the criteria for an award, and warned that $\mathrm{NIH}$ reserved the right to monitor grantee patenting activity. ${ }^{93}$

The hortatory efforts of NIH to constrain its grantees in pursuing intellectual property rights have not been limited to genome-related projects. A more general statement of "Principles and Guidelines for Sharing of Biomedical Research Resources," adopted by NIH in December 1999, also attempts to guide NIH grantees in the deployment of their proprietary rights. These principles state that:

The use of patents and exclusive licenses is not the only, nor in some cases the most appropriate, means of implementing the [Bayh-Dole] Act. Where the subject inven-

85. NHGRI Policy Regarding Intellectual Property of Human Genomic Sequence (April 9, 1996), available at $\mathrm{http}: / /$ www.nhgri.nih.gov/Grant_info/Funding/Statements/RFA/intellectual_property.html.

86. See supra note 24.

87. See NHGRI Policy, supra note 85.

88. Id.

89. Even university technology transfer offices, whose institutional culture and self-interest promote a commitment to patenting that is probably stronger than that of the research science community itself, did not challenge the policy. See supra note 84, at 478 (noting that key university patent officials endorsed policy). Some leading officers did, however, admit to being wary of the "bad precedent" that the April 1996 policy might set. Id. (quoting Lita Nelsen of MIT).

90. National Institutes of Health RFA HG-98-001, Methods for Discovering and Scoring Single Nucleotide Polymorphisms (Jan. 9, 1998), available at http://grants.nih.gov/grants/guide/rfn-files/RFAHG-98-001.html.

91. See id.

92. See id.

93. See id. 
tion is useful primarily as a research tool, inappropriate licensing practices are likely to thwart rather than promote utilization, commercialization, and public availability."

One factor that counsels in favor of wide dissemination of a particular invention is its status as "a broad, enabling invention that will be useful to many scientists, or multiple companies in developing multiple products, rather than a project or product-specific resource." ${ }^{95}$ In addition, the Principles and Guidelines urge universities to exchange all unpatentable research tools freely, both within the academic community and with industry. ${ }^{96}$

The goals that NIH has sought to promote through these various hortatory statements are broadly consistent with the stated goal of the Bayh-Dole Act: "[T]o promote the utilization of inventions arising from federally supported research or development. ${ }^{, 97}$ Arguably, NIH has acted outside the scope of its statutory authority, however, at least with respect to patentable inventions, leaving itself vulnerable to a potential legal challenge from a recalcitrant grantee..$^{98}$

Consider, for example, NIH's suggestion that it would find the filing of university patents on large blocks of primary human genomic DNA sequence "problematic." "The only legal authority that the NIH has for restricting patenting is the "exceptional circumstances" clause of the Bayh-Dole Act. ${ }^{100}$ Therefore, since NIH specifically chose not to rely upon the clumsy administrative procedure required by that clause, its suggestion has no legal authority whatsoever. The same holds true for NIH's general policy statement of Principles and Guidelines for the Sharing of Biomedical Research Resources. ${ }^{101}$ Indeed, NIH has no authority under the Bayh-Dole Act to issue broadly applicable substantive regulations concerning the licensing of inventions (as distinguished from making specific determinations regarding march-in rights in the context of particular grants). ${ }^{102}$ Congress specifically conferred the broader power to promulgate such regulations on the Commerce Department, not the

94. Department of Health and Human Services, National Institutes of Health, Principles and Guidelines for Recipients of NIH Research Grants and Contracts on Obtaining and Disseminating Biomedical Research Resources: Final Notice, 64 Fed. Reg. 72,090, 72,093 (Dec. 23, 1999).

95. Id. at 72,094. Other factors include whether the invention is primarily useful as a tool for discovery rather than as an FDA-approved product or component of such product and whether the resource is readily usable, without the need for private sector involvement in further development. Id.

96. $I d$.

97. 35 U.S.C. $\$ 200(2000)$.

98. With respect to inventions that are not patentable, NIH presumably has greater discretion in constraining proprietary activity. Because many inventions fall into a grey area with respect to patentability, however, a decision by NIH to force free exchange of unpatented material may, in the absence of other reform, simply lead some grantees to patent more aggressively. To forestall this possibility, NIH needs to be given more control over the patenting activities of grantees.

99. See NHGRI Policy, supra note 85.

100. 35 U.S.C. $\$ 202(a)(i)-(i i)$.

101. See 64 Fed. Reg. 72,090 .

102. 35 U.S.C. $\$ 203$. 
funding agencies. ${ }^{103}$ NIH's attempted departures from the Bayh-Dole Act's grant of broad discretion concerning patenting and licensing to grantee institutions would thus appear to have little legal weight. ${ }^{104}$

The success that NIH has enjoyed thus far in its efforts to constrain the proprietary strategies of grantees may reflect the continuing vitality of norms of free exchange, at least among a subset of academic researchers. ${ }^{105}$ Researchers, and even their associated institutions, might voluntarily acquiesce in abiding by these norms, or at least balk at mounting an open challenge.

But there is growing evidence that NIH may require authority beyond the bully pulpit to ensure continuing compliance with these norms in the future. ${ }^{106}$ Consider, for example, the recent controversy over the broad patent held by WARF on primate embryonic stem cells. ${ }^{107}$ Although embryonic stem cells are precisely the type of broadly applicable enabling technology that, as a general matter, should be licensed nonexclusively in the interest of promoting future research and product development, WARF chose to license exclusively some of the most important commercial rights under the patent. ${ }^{108}$ To be sure, the WARF case is somewhat unusual in that the exclusive licensee, Geron, provided crucial funding at a point when the federal government felt legally prohibited from funding the research necessary to move from chimpanzee and monkey cell lines to human cell lines. ${ }^{109}$ But even if the federal government had provided all of the funding, WARF could still have decided to license the invention exclusively, at least with respect to certain fields of use, rather than to follow the Cohen-Boyer model of nonexclusive licensing. Although NIH might, in theory, exercise its march-in rights to make the invention more broadly available, these rights would be held in abeyance until all court appeals were exhausted, meanwhile delaying use of the invention in research. ${ }^{110}$ Given this legal backdrop, it is unsurprising that recent negotiations between WARF and

103. 35 U.S.C. $§ 208$ ("The Secretary of Commerce is authorized to promulgate regulations specifying the terms and conditions upon which any federally owned invention ... may be licensed on a nonexclusive, partially exclusive, or exclusive basis.")

104. See United States v. Mead, 533 U.S. 218, 226-7 (2001) (noting that administrative implementation of a particular statute qualifies for "strong" deference under the Chevron doctrine, Chevron USA, Inc. v. Natural Resource Defense Council, Inc., 467 U.S. 837 (1984), only "when it appears that Congress delegated authority to the agency generally to make rules carrying the force of law, and that the agency interpretation claiming deference was promulgated in the exercise of that authority")

105. See generally Rai, Regulating Scientific Research, supra note 45.

106. Cf. id. at 151 (suggesting that, to the extent greater authority were needed to rein in federal grantees who violated open science norms, the Bayh-Dole Act could be amended).

107. See Thomson, supra note 23.

108. Wisconsin Alumni Research Foundation's Brief in Opposition to Geron Corporation's Fed. R. Civ. Pro. 12(c) Motion for Judgment on the Pleadings, Wisconsin Alumni Research Foundation v. Geron, Case No. 01-C-0459-C at 2 (on file with author).

109. See NATIONAL ReseARCH COUnCIL AND InStitute OF Medicine, supra note 23.

110. 35 U.S.C. $§ 202(b)(1)$. 
NIH over use of embryonic stem cell lines in research left WARF maintaining tight control over commercial applications of the technology. ${ }^{111}$

As patenting by universities gains momentum, the normative baseline in the academic community concerning free exchange appears to have shifted. Twenty-five years ago, universities thought long and hard before filing a patent application on such a fundamental discovery as gene-splicing, yet today they proclaim an entitlement to control and profit from commercial use of their government-sponsored inventions without apology for resulting restrictions on subsequent research and development. In this environment we expect to see increasing departures from norms that previously constrained proprietary behavior.

\section{$\mathrm{V}$ \\ ENHANCING THE LEGAL AUTHORITY OF NIH}

The time is ripe to fine-tune the Bayh-Dole Act to give funding agencies more latitude in guiding the patenting and licensing activities of their grantees. More generally, Congress should recognize that patenting and exclusive licensing are not always the best way to maximize the social value of inventions and discoveries made with federal funds. We propose two modest reforms that would further these goals.

First, the circumstances in which an agency may depart from the statutory presumption that the contractor may retain title to an invention in the terms of particular grants should be liberalized. The current "exceptional circumstances" language creates a clear presumption that the agency should exercise its power to restrain patenting only infrequently. ${ }^{12}$ This parsimonious approach unduly constrains the authority of agencies such as NIH to use federal funding to enrich the public domain. Once the "exceptional circumstances" language is deleted, the substantive standard set forth in the current statutory language, which permits departure from the usual rule "when it is determined by the agency that restriction or elimination of the right to retain title to any subject invention will better promote the policy and objectives of this chapter," be more freely applied to achieve the legislative goal of promoting widespread dissemination and use of research results. The current cumbersome administrative process for review of such determinations should be streamlined as well, with provision for research to proceed while the review process runs its course..$^{14}$

111. Memorandum of Understanding Between NIH and Wicell (Sept. 5, 2001), available at http:// www.nih.gov/news/stemcell/WicellMOU.pdf.

112. Thus, even though courts would presumably have to show Chevron deference to an agency finding of "exceptional circumstances," such deference would be in tension with the idea that the agency is (by definition) not supposed to find exceptional circumstances in too many cases.

113. 35 U.S.C. $\$ 202(a)(i i)$.

114. To be sure, action ex ante may be problematic to the extent that it may sometimes be difficult to determine at the outset whether particular research is best distributed broadly or under a regime of 
Second, with respect to the "march-in" right of funding agencies, the requirement that march-in authority be held in abeyance pending exhaustion of all court appeals by the government contractor should be changed. Indeed, the tolerance for protracted delays inherent in the current process is at odds with the time-sensitive nature of the interests reflected in the substantive standard, such as achieving practical application of the invention "within a reasonable time" and "alleviat[ing] health or safety needs." 115 An agency, however, should not be given march-in authority without adequate provision for judicial review. Unlike a prospective agency determination to restrict patenting at the grant stage before any invention has been made, a subsequent exercise of march-in rights disturbs settled expectations of grantees and licensees that may underlie investments. If these expectations are too readily upset by the exercise of march-in rights, industry could become wary of investing in university-based technology.

It might be argued that restoring greater authority to agencies would return us to the unhappy position that motivated Congress to pass the Bayh-Dole Act twenty-two years ago. Then, Congress acted to eliminate the uncertainty and delay associated with agency discretion over the patent rights available to contractors. ${ }^{116}$ At least with respect to NIH, an agency that was singled out as a cause of concern in the legislative history of the Bayh-Dole Act, this danger appears quite small today. In the intervening years NIH has embraced patenting and technology transfer in furtherance of its public health mission. ${ }^{117}$ Moreover, our proposal to give agencies greater authority would not overturn the general presumption in favor of allowing government contractors to patent inventions. It would simply permit agencies to decide that patenting is not warranted in particular cases, while streamlining procedures for making and reviewing these decisions. Greater discretion for agencies would also correct a dangerous oversimplification of how best to achieve the important policies underlying the Bayh-Dole Act by recognizing that patenting and exclusive licensing are not necessarily the best way to go.

A skeptic influenced by public choice theory might fear that our proposal would tempt agencies like NIH to use their discretion to justify an allocation of greater resources to expand their own roles. ${ }^{118}$ NIH might invoke ostensibly public-spirited arguments for public funding as a means of promoting widespread access to research results, when in fact these arguments would cover self-

property rights. As discussed in the text, however, action ex post is problematic to the extent that it may disturb settled expectations of grantees and licensees.

115. 35 U.S.C. $\$ 203(a)$, (b).

116. For example, the Senate report on the statute that would become the Bayh-Dole Act observed that "[p]resently, there are at least 24 different patent policies in effect in the Federal agencies. There are frequently contradictory from agency to agency (and even sometimes within the same agency) and have proven to be formidable barriers to organizations interested in participation in Government work." S. REP. NO. 96-480, at 2 (1979).

117. See supra note 73 and accompanying text.

118. See, e.g., William A. NiskaKen, JR., BUREAUCRACY AND REPRESENTATIVE GovernMENT 114 (1971). 
serving efforts to expand the scope of its own research, even in research areas where the private sector is already operating. These public-spirited arguments, however, have considerable force. When the willingness of private firms to do research depends on their ability to restrict the dissemination of research results, public funding may be essential to ensure that basic research discoveries are widely disseminated. That arguments for public funding of research in the public domain might in fact be driven by agency self-interest does not, in and of itself, detract from the soundness of the arguments.

While the public choice theorist might worry about agency self-aggrandizement, the policy analyst might be concerned that NIH does not have the expertise to make sophisticated judgments about when research should be left in the public domain. To put the point another way, although NIH scientists may have an intuition about what type of research belongs in the public domain, this intuition may not always be economically well-grounded. The intuition of scientists could, however, be supplemented by the expertise of policy analysts who specialize in innovation. NIH might employ such experts on its staff, perhaps in the Office of Technology Transfer ("OTT"), or it could include such expertise in the composition of its external advisory boards.

One might also worry that giving NIH greater discretion to mandate dedication of research results to the public domain would cause some university researchers to forsake public funding in favor of funding from industry. Given that private sector funding generally comes with very significant proprietary constraints, such defection might result in a net loss for the public domain. Although this is a reasonable concern, we do not see it as a serious threat. Unless universities act collectively to boycott federal funding in a particular research area, some university researchers will presumably be willing to take $\mathrm{NIH}$ funds to conduct their research in the public domain, limiting the attractiveness to industry of allocating private funds to the same purpose. Moreover, despite the increasingly intimate ties between universities and industry, NIH funding is not only much more extensive than private funding for universitybased research, but it remains the coin of the realm for tenure, promotion, and other measures of academic success. ${ }^{119}$ Unless that situation changes dramatically, significant defections from peer-reviewed public funding seem unlikely. Moreover, given that NIH leadership is typically drawn from the same community of scientists as university researchers, ${ }^{120}$ the agency is unlikely to drift too far from the concerns of the community it regulates. Thus, to the extent that $\mathrm{NIH}$ tries to ensure compliance with open access norms, it is likely to use

119. As noted earlier, NIH still funds the vast majority of university-based research in the life sciences. See supra note 21. Moreover, of the 75 American Nobel laureates in physiology or medicine in the period from 1945-1998, 56 had either worked at NIH or were supported by NIH prior to winning the prize. See NIH Funds Support Nobel Laureates, at http://www.nih.gov/news/NIH-Record/11_03_ 98/story06.htm (last visited Jan. 22, 2003).

120. For example, the current NIH Director, Elias Zerhouni, was a professor at Johns Hopkins University. The previous NIH Director, Harold Varmus, is a Nobel-prize winning molecular biologist who now heads the Memorial Sloan-Kettering Cancer Institute. 
"gentle nudging" rather than destabilizing "hard shoves." Indeed, far from being destabilizing to the scientific community, NIH action could strengthen the position of university scientists who favor open access vis-à-vis those university constituencies that are less supportive of open access.

Finally, one might be concerned that funding agencies such as NIH might use their expanded discretion over patenting decisions to respond to political pressures unrelated to the legitimate goal of mediating the tension between access and product development. For example, an executive branch that was motivated to suppress controversial research might be unable to convince Congress to withhold funding for such research entirely, but could decide unilaterally to withhold patents on the research, in the hope that, absent patent protection, the research might never be developed for commercial use. This is a serious concern, particularly given the political heat surrounding many promising areas of biomedical research, such as research that involves human embryos. ${ }^{122}$ Although we have no illusions that public sector research can be completely insulated from political controversy, we hope and expect that judicial review of agency determinations would provide a check on an agency's use of its discretion under the Bayh-Dole Act to advance agendas unrelated to research and development.

\section{VI \\ CONCLUSION}

As proprietary claims have proliferated in biomedical research, the costs that patents impose on $R \& D$ have become more salient. At the same time, patents on biomedical research discoveries plainly offer important social benefits in the form of motivating further private investment in product development. The presumption that patent incentives are necessary to promote research and development has less force for inventions arising from government-sponsored research than for inventions arising from purely private funding. It is therefore important that decisions about patenting the results of government-sponsored research be made on the basis of a careful balancing of the costs and benefits that they entail for future R\&D. Current law entrusts these decisions to the unbridled discretion of institutions, such as universities, that receive federal funds, but these institutions are inadequately motivated to take the social costs of their proprietary claims into account in deciding what to patent. A more sensible approach would give research sponsors, such as NIH,

121. Cf. Dan Kahan, Gentle Nudges vs. Hard Shoves, 67 U. CHI. L. REV. 607 (2000) (arguing that decision-makers charged with implementing laws that seek to change social norms will be more likely to implement laws that do not represent a radical break with governing practices).

122. Similar concerns might arise for research that could be used for terrorist purposes. The BayhDole Act already provides that agencies that have responsibility for national security can act to restrict or eliminate patents that affect security. 35 U.S.C. $\S 202$ (2000). Our proposal does not alter the allocation of power with respect to that issue. 
more authority to restrict patenting of publicly-funded research when such patenting is more likely to retard than promote subsequent $R \& D$. 